\title{
OXIDATIVE STRESS INDUCED BY GLYPHOSATE-BASED HERBICIDE ON FRESHWATER TURTLES
}

\author{
Laurent HÉRITIER,${ }^{\mathrm{a}, \mathrm{b}, *}$ David DUVAL,${ }^{\mathrm{c}}$ Richard GALINIER,${ }^{\mathrm{c}}$ Anne-Leila MEISTERTZHEIM,, $\mathrm{a}$ \\ and Olivier VERNEAU ${ }^{\mathrm{a}, \mathrm{b}, \mathrm{d}}$
}

a- Universite de Perpignan Via Domitia, Centre de Formation et de Recherche sur les Environnements Mediterraneens, Perpignan, France

b- CNRS, Centre de Formation et de Recherche sur les Environnements Mediterraneens, Perpignan, France

c- $\quad$ IHPE-Interactions $\mathrm{H}^{\wedge}$ otes-Pathogenes-Environnements, Perpignan, France

d- Unit for Environmental Sciences and Management, North-West University, Potchefstroom, South Africa

Corresponding author : laurent.heritier@univ-perp.fr

\begin{abstract}
:
Freshwater ecosystems face very strong anthropogenic pressures, among which overexploitation, habitat degradation, flow modification, species invasion, and water pollution lead to growing threats on biodiversity. Urbanization through wastewater treatment, industry through the release of inorganic and organic chemicals, and agriculture through the use of pesticides and herbicides are the main factors involved in water pollution. In France, more precisely in the Pyrenees-Orientales department, the poor quality of the watercourses is attributable overall to the use of glyphosate-based herbicides in agricultural activities. Because these chemicals can impact individuals, populations, and biodiversity, we investigated, under experimental conditions, the physiological response of animals facing abiotic contaminants. We selected as a model, juveniles of the freshwater turtle Trachemys scripta elegans. We measured the gene expression and activity of the catalase and superoxide dismutase enzymes as well as the levels of lipid peroxidation, which are all oxidative stress biomarkers, in turtles challenged with high concentrations of glyphosate-based herbicides, on the one hand, and with degraded waters collected from a local watercourse, on the other. We also measured the acetylcholinesterase activity across the same animals. We showed through variations in gene expression and enzyme activity that a glyphosate commercial formulation induced a stress in turtles. A similar outcome was obtained when turtles faced degraded waters. The results indicated that the poor quality of regional waters could be a real threat for animal health. Because turtles are globally less sensitive to contaminants than amphibians, which are lacking in the degraded waters of the Pyrenees-Orientales department, they could constitute an excellent model to follow the evolution of water quality through the study of oxidative stress biomarkers.
\end{abstract}

\section{KEYWORDS:}

Trachemys scripta elegans ; Mauremys leprosa ; Oxidative stress ; Glyphosate Catalase ; Superoxide dismutase ; Gene expression ; Enzyme activity 


\section{INTRODUCTION}

Freshwater ecosystems are remarkable natural habitats that provide multiple ecological services via hydrological properties, water resources, and climate regulation. As such, they have a significant economic value and contribute to human wellbeing. Though they represent only $<1 \%$ of the earth's surface, they comprise a great diversity of species with no less than 100000 animal species known to date, which corresponds to approximately $9.5 \%$ of the current animal diversity [1,2]. However, freshwater ecosystems face strong pressures from human activities, which lead to growing threats to biodiversity [3]. They are likewise considered more imperiled than their terrestrial and marine counterparts [1,3]. If freshwater research is indeed regarded as less sexy than marine research, trajectories of species loss make it arguably the most urgent [4]. It is therefore crucial to pursue and undertake intensive surveys on freshwater ecosystems to protect and manage aquatic biodiversity.

Among the many factors initiating the loss of freshwater biodiversity, the most important remain overexploitation, habitat degradation, flow modification, species invasion, and water pollution [5-7]. Regarding pollution of freshwaters, different causes can be invoked either naturally, like spring floods, fair weather periods, and biogenetic agents, or anthropogenically, through chemical and biological means, which constitute the primary sources of environmental contamination [8]. The latter are usually the effect of urbanization through wastewater treatment, industry through the release of inorganic and organic chemicals, and agriculture through the use of pesticides and herbicides. The most common pollutants that are typically found within freshwaters then depend not only on the source of contamination but also on the climate and geographical area $[9,10]$. Because intensive agricultural activities exist in France, numerous pesticides andherbicidesare still commonly used. As a consequence, some chemicals are released in freshwater ecosystems, among others atrazine, diuron, imidaclopride, and glyphosate [11].

The commercial formulations of glyphosate-based herbicides are composed of a mixture of isopropylamine salt of glyphosate and polyethoxylated tallowamine, which is the predominant non-ionic surfactant [12]. The toxicity of these commercial formulations, as well as the toxicity of their active compounds alone and the main degradation product of glyphosate, namely aminomethylphosphonic acid (AMPA), have been well studied across vertebrates, such as fishes, amphibians, and mammals. It has been shown under experimental conditions that commercial formulations were actually more toxic than glyphosate alone. This was deduced through studies of gene expression, mortality, and teratology in tadpoles [13]; mitochondrial bioenergetic functions in rats [14]; and cellular damage and endocrine disruption in human cells [15,16]. Subsequently, activity studies of acetylcholinesterase (AChE) and oxidative stress enzymes, as well as measures of metabolic parameters and examination of cellular damage, were conducted in fishes [17-21] and amphibians [22-24]. Because results showed disturbance in the physiological parameters of these organisms, active ingredients of herbicides and their degradation products, which are common in aquatic ecosystems, could impact local biodiversity, from a chronic nonlethal physiological stress response to the death of individuals and population extinction [20,21,23].

In southern France, more specifically in the PyreneesOrientales department, agricultural activities are mainly based on fruit cropsand vineyards. Thesecould explain theoccurrence of herbicide active ingredients in the main watercourses, like in the Tech [25] and $\mathrm{T}^{\wedge}$ et [10] Rivers, but also in some minor rivers, like in the Agouille de la Mar, Baillaury, and Fosseille Rivers [25]. The relatively high concentrations of glyphosate and AMPA in the freshwaters of the Agouille de la Mar and the Fosseille have led to a downgrading of both rivers, which are currently classified in the worst of the 5 listed categories used to evaluate water quality. These 2 rivers are nevertheless home to several semi-aquatic and aquatic vertebrate species, among them the Mediterranean pond turtle Mauremys leprosa (Schweigger, 1812). This species, which occurs almost exclusively in the Pyrenees-Orientales department in France (see Palacios et al. [26]), has been classified as "vulnerable" [27]. In the Fosseille River, with approximately 250 individuals (O. Verneau, unpublished data), the turtle population is ranked as the second greatest of the Pyrenees-Orientales department after that of the Baillaury River, whose population was estimated at 315 individuals [28]. 
Although 2 main threats may pose a risk for M. leprosa in natural environments, namely the invasive redeared slider Trachemys scripta elegans (Wied, 1839) that occurs in the same area and that can compete for basking, territory, and feeding resources [29-31], and its parasites that are transmitted to the indigenous turtles [32], the presence of glyphosate andAMPA in theAgouille de laMar and Fosseille Rivers could constitute another threat to the native freshwater turtle.

Regarding the poor quality of some watercourses in the Pyrenees-Orientales department, which is likely attributable to the use of glyphosate-based herbicides, one may wonder if these chemicals can impact some physiological parameters in the Mediterranean pond turtle. The first objective of the present study was therefore to identify biomarkers to assess the physiological stress response of turtles facing high concentrations of glyphosate-based herbicides. A second objective was to measure the activity of these biomarkers to evaluate the response of turtles facing degraded waters. Because M. leprosa benefits from very strict rules of protection in France, an experimental design on that species to investigate stress induced by glyphosate formulations was inconceivable. We therefore selected juveniles of captive T. s. elegans turtles for ex situ experiments. The gene expression of catalase (CAT) and superoxide dismutase (SOD) was measured from liver samples, and the enzymatic activity of CAT, SOD, and AChE, as well as the levels of lipid peroxidation, were measured from blood samples. A third objective was to test the applicability of our approach, that is, assessing the gene expression and activity of CAT and SOD biomarkers in blood collected from captive M. leprosa turtles to conceive environmental ecotoxicological studies without euthanizing animals.

\section{MATERIALS AND METHODS \\ Experimental animals}

Thirty juvenile T. s. elegans, born at the Turtles Farm of Sorede (Pyrenees-Orientales department, France), were maintained for $1 \mathrm{mo}$ in captivity. Turtles were subsequently kept for 2 mo at the laboratory in 20-L water tanks preheated to $25^{\circ} \mathrm{C}$ (15 turtles/tank) and equipped with ultraviolet (UV) lamps (5.0 UVB Reptiles; Exo Terra) and basking sites for acclimation. Turtles were fed every $2 \mathrm{~d}$ with commercial freshwater turtle food (Aquatic Turtle Food; ZooMed) until 48h before the beginning of experiments. Carapax length ranged from 3 to $4 \mathrm{~cm}$, and weight was between 10 and $15 \mathrm{~g}$.

Eleven juvenile M. leprosa, born in captivity at the Zoodyssee Zoological Park of Chize (Deux-Sevres department, France), were maintained altogether for 6 mo in an aquarium filled with approximately 250L of water. Carapax length ranged from 2.5 to $3.5 \mathrm{~cm}$, and weight was between 5 and $10 \mathrm{~g}$.

\section{Experimental design}

For T. s. elegans, after an acclimation period of 2 mo, turtles were divided into 6 groups of 5 individuals each in containers that were devoid of basking sites and filled with $5 \mathrm{~cm}$ of water. Because responses in enzyme activity are usually recorded between 6 and $96 \mathrm{~h}$ after exposure [20,21,33], half of the experimental groups of animals were analyzed $12 \mathrm{~h}$ after exposure and the other half $96 \mathrm{~h}$ after exposure. Two groups among the 6 were maintained in tap water for 12 and $96 \mathrm{~h}$, respectively. These 2 groups served as the control groups and were named the "control-12 h" and "control- $96 \mathrm{~h}$ " groups for convenience. Because the median lethal concentration (LC50) at $96 \mathrm{~h}$ is $36.8 \mathrm{mgL}^{1}$ of Roundup ${ }^{1}$ (commercial formulation of glyphosate-based herbicide, 360g glyphosate $\mathrm{L}^{1}$; Monsanto) for adults of the Nile tilapia (Oreochromis niloticus) [34] and because the LC50 at $48 \mathrm{~h}$ is $49.4 \mathrm{mgL}^{1}$ of Roundup for adults of the sign-bearing froglet (Crinia insignifera) [35], 2 groups were exposed for 12 and $96 \mathrm{~h}$, respectively, to Clinic (commercial formulation of glyphosatebased herbicide, $360 \mathrm{~g}$ glyphosate $\mathrm{L}^{1}$; Nufarm) at a glyphosate concentration of $30 \mathrm{mg} \mathrm{L}^{1}$ that was assumed to be nonlethal. These 2 groups were named the "glyphosate-12 h" and "glyphosate- $96 \mathrm{~h}$ " groups for convenience. Finally, 2 groups were exposed to water collected from the Fosseille River in September 2015, 12 and $96 \mathrm{~h}$, respectively. These 2 groups were named the "Fosseille- $12 \mathrm{~h}$ " and "Fosseille- $96 \mathrm{~h}$ " groups for convenience. Two blood samples of $150 \mathrm{~mL}$ each were systematically collected per individual by the end 
of experiments. Blood was drawn from the subcarapacial sinus using insulin syringes, collected in tubes including 1mg K2-ethylenediaminetetraacetic acid (EDTA), and immediately frozen in liquid nitrogen. Samples were subsequently preserved at $-808 \mathrm{C}$ until biochemical and molecular experiments. Finally redeared sliders were euthanized by cardiac injection of $10 \%$ sodium pentobarbital (Euthapent) and dissected. Organs were frozen in liquid nitrogen and subsequently preserved at $-80^{\circ} \mathrm{C}$.

For M. leprosa, 2 blood samples of $150 \mathrm{~mL}$ each were collected per individual at the Zoodyssee Zoological Park. Blood was drawn from the subcarapacial sinus using insulin syringes, collected in tubes including $1 \mathrm{mg}$ K2-EDTA, and immediately frozen in liquid nitrogen. Samples were subsequently preserved at $-808 \mathrm{C}$ until biochemical and molecular experiments.

\section{Gene expression of CAT and SOD}

RNA extraction and reverse transcription. Total RNA extractions were performed from pieces of liver because it was impossible to get enough blood from the very small redeared sliders for measuring both molecular and biochemical activities. Extractions of RNA were, however, completed only from blood samples of M. leprosa. Regardless of host tissues, Trizol Reagent (Life Technologies) was used following the methodological procedure of the manufacturer. Blood $(250 \mathrm{~mL})$ and $100 \mathrm{mg}$ of liver were mixed separately with $1 \mathrm{~mL}$ of Trizol and $200 \mathrm{~mL}$ of chloroform and subsequently incubated for $5 \mathrm{~min}$ at room temperature. Mixtures were centrifuged at $12000 \mathrm{~g}$ and $48 \mathrm{C}$ for $15 \mathrm{~min}$ before transferring the aqueous phase in sterile tubes. After another centrifugation step of $15 \mathrm{~min}$ at $12000 \mathrm{~g}$ and $48 \mathrm{C}$, RNAs were precipitated using $0.5 \mathrm{~mL}$ of isopropanol. Finally, RNAs were washed with $85 \%$ frozen ethanol and dissolved in pure water. The quality and concentration of RNA were assessed by spectrophotometry at $280 \mathrm{~nm}$ (Nanodrop ND1000; Thermo Fisher Scientific). One microgram of total RNA ( $5 \mathrm{~mL}$ at $200 \mathrm{ngmL}^{1}$ ) was reversetranscribed using the Maxima $\mathrm{H}$ Minus first-strand cDNA synthesis kit (Thermo Scientific). Complementary DNAs were diluted at 1/20 until use for real-time polymerase chain reaction (PCR).

Real-time PCR. The LightCycler ${ }^{1}$ Probe Design ${ }^{\mathrm{TM}}$ Software (Roche Diagnostics), Ver 1.0, was first used to design specific primers from the complete 18SrRNA gene (accession number M59398) and partial CAT and SOD gene sequences (accession numbers JX508630 and FJ834442, respectively) of the red-eared slider T. s. elegans. The following forward and reverse primers were used for real-time PCR in both species, T. s. elegans and M. leprosa: 18SQTseF, 50-CCAGTAAGTGCGGGTCATAAGC-3 ${ }^{0}$; 18SQTseR, $5^{0}$ GACCTCA CTAAACCATCCAATCG- ${ }^{0}$; CATQTseF, $5^{0}$-TCGCTGGAGAGTCTGGTTCA- $3^{0}$; CATQTseR, $\quad 5^{0}$-ACAAGATCCCA-GATACCCTCTTCTG- $3^{0} ; \quad$ SODQTseF, $\quad 5^{0}$-CGGCCTTGGTC CTGGTTAA- $3^{0}$; and SODQTseR, $5^{0}$-CGGCAGTATCGGTTG GTGTT- $3^{0}$. Amplification experiments were performed with a LightCycler apparatus (Roche Molecular Biochemicals) in a final volume of $10 \mathrm{~mL}$ containing LightCycler 480 SYBR Green I Master Mix 1final concentration, primers at $0.4 \mathrm{mM}$, and $2 \mathrm{~mL}$ of cDNA. Cycling conditions were as follows: one cycle of $14 \mathrm{~min}$ of preincubation at $958 \mathrm{C}$, followed by 45 cycles of $11 \mathrm{~s}$ of denaturation at $958 \mathrm{C}, 11 \mathrm{~s}$ of annealing at $608 \mathrm{C}$, and $19 \mathrm{~s}$ of elongation at $728 \mathrm{C}$. The specificity of all primers was tested by the presence of a single peak observed within the melting curves. The $2^{-\mathrm{DDCT}}$ method was used for analyzing relative changes in gene expression [36]. Data sets were normalized to the $18 \mathrm{~S}$ rRNA reference gene.

\section{Enzyme activity of CAT, SOD, and AChE}

Because we had no idea of the blood fractions within which to measure enzyme activity, we used whole blood for determining CAT, SOD, and AChE activities and for quantifying lipid peroxidation levels.

CAT activity. Five microliters of blood were diluted in $200 \mathrm{~mL}$ of cold assay buffer from the Catalase Activity Colorimetric/Fluorometric Assay Kit (BioVision). The mixture was centrifuged at $10000 \mathrm{~g}$ and $48 \mathrm{C}$ for $15 \mathrm{~min}$, and $40 \mathrm{~mL}$ of the supernatant were subsequently used for measuring enzyme activity at $570 \mathrm{~nm}$ following the manufacturer's recommendations. Activity of CATwas expressedin milliunits 
permilligram of protein. The biochemical procedure was performed for both turtle species only from blood samples.

SOD activity. Five microliters of blood were diluted in $995 \mathrm{~mL}$ of distilled deionized ultrapure water. The mixture was centrifuged at $10000 \mathrm{~g}$ and $48 \mathrm{C}$ for $15 \mathrm{~min}$, and $20 \mathrm{~mL}$ of the supernatant were subsequently diluted in $200 \mathrm{~mL}$ of WST working solution from the Superoxide Dismutase (SOD) Activity Assay Kit (BioVision) for measuring enzyme activity at $450 \mathrm{~nm}$ following the manufacturer's recommendations. Superoxide dismutase activity was expressed in units per milligram of protein. The biochemical procedure was performed for both turtle species only from blood samples.

AChE activity. Five microliters of blood were used in combination with the components from the Acetycholinesterase Activity Colorimetric Assay Kit (Biovision) for measuring enzyme activity at 570nm following the manufacturer's recommendations. Acetycholinesterase activity was expressed in milliunits per milligram of protein. The biochemical procedure was performed from blood samples of T. s. elegans only.

\section{Quantification of lipid peroxidation}

Twenty microliters of blood were diluted in $300 \mathrm{~mL}$ of lysis buffer from the Lipid Peroxidation Colorimetric/Fluorometric Assay Kit (BioVision). The mixture was centrifuged at $10000 \mathrm{~g}$ and $48 \mathrm{C}$ for $15 \mathrm{~min}$, and $200 \mathrm{~mL}$ of the supernatant were subsequently used for the quantification of lipid peroxidation at $532 \mathrm{~nm}$ following the manufacturer's recommendations. Levels of lipid peroxidation were expressed in nanomoles per milligram of protein. The biochemical procedure was performed from blood samples of $\mathrm{T}$. s. elegans only. The quantification of total proteins in all samples, which allows one to report enzymatic activity per milligram of protein, was done following the method of Lowry et al. [37].

\section{Statistical analyses}

Variations in gene expression, enzyme activity, and lipid peroxidationquantification wereanalyzed acrossthe6groupsof turtles (control-12h, control-96h, glyphosate-12h, glyphosate96h, Fosseille-12h, and Fosseille-96h) for each measure (SOD gene expression, SOD enzyme activity, CAT gene expression, CAT enzyme activity, AChE enzyme activity, and lipid peroxidation quantification) following the nonparametric Kruskal-Wallis test using SPSS Statistics 17.0 (SPSS). Pairwise comparisons for each measure were subsequently done following the nonparametric Mann-Whitney U test using SPSS Statistics 17.0. Statistical significance was accepted at $\mathrm{p}<0.05$.

\section{RESULTS}

\section{Gene expression of CAT and SOD within T. s. elegans}

Variations in CAT gene expression between the 6 groups of turtles (control-12h, control-96h, glyphosate12h, glyphosate96h, Fosseille-12h, and Fosseille-96h) were observed (Kruskal-Wallis, p¹/40.018). Pairwise comparisons revealed no significant variation between the groups sampled $12 \mathrm{~h}$ after exposure (Figure 1A). On the contrary, the CAT gene expression profile within the glyphosate-96-h group was 2.8 -fold higher than that of the control-96-h group (Mann-Whitney, p⿳亠丷厂甲40.008), and the Fosseille-96-h group showed a gene expression profile 2.1-fold higher than that of the control-96-h group (Mann-Whitney, $\mathrm{p}^{1 / 40.032}$ ). No significant variation was observed between the glyphosate-96-h and Fosseille-96-h groups (Figure 1B). Variations in the SOD gene expression profile between the 6 groups of turtles were observed (Kruskal-

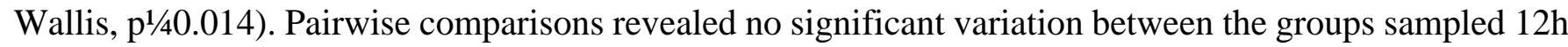
after exposure (Figure 2A). On the contrary, the glyphosate-96-h group showed a gene expression profile 3.4-fold higher than that of the control-96-h group (Mann-Whitney, $\mathrm{p}^{1 / 40.008)}$ ), and the Fosseille-96-h group showed a gene expression profile 2.2-fold higher than that of the control-96-h group (Mann-Whitney,

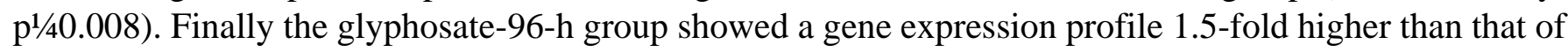
the Fosseille-96-h group (Mann-Whitney, p⿳⺈⿴囗十 0.008; Figure 2B). 


\section{Enzyme activity of CAT, SOD, and AChE within T. s. elegans}

Variations in CAT activity between the 6 groups of turtles were observed (Kruskal-Wallis, p 1/40.001). The glyphosate12-h group showed an enzyme activity profile 1.3-fold lower than that of the control-12-h (Mann-Whitney, p 1/40. 01) and Fosseille-12-h (Mann-Whitney, $\mathrm{p}^{1 / 40.008)}$ groups. No significant difference was observed between the control12-h and Fosseille-12-h groups (Figure 3A). In addition, the glyphosate96-h group showed an enzyme activity profile 1.5-fold higher than that of the control-96-h group (MannWhitney, $\mathrm{p} 1 / 40.016$ ), and the Fosseille-96-h group showed an enzyme activity profile 1.9-fold higher than that of the control-96-h group (Mann-Whitney, $\mathrm{p}^{1 / 40.016)}$ ). No significant difference was observed between the glyphosate96-h and Fosseille-96-h groups (Figure 3B). Surprisingly, the control-12-h group showed an enzyme activity profile 1.7-fold higher than that of the control-96-h group (Mann-Whitney, $\mathrm{p}^{1 / 40.02}$ ).

Variations in SOD activity between the 6 groups of turtles were observed (Kruskal-Wallis, p $1 / 40.013$ ). Pairwise comparisons revealed no significant variation between the groups sampled $12 \mathrm{~h}$ after exposure (Figure 4A). In addition, the glyphosate-96-h group showed an enzyme activity profile 1.6-fold lower than that of the control-96-h group (Mann-Whitney, $\mathrm{p}^{1 / 40.008)}$ ). No significant difference was observed between the control-96-h and Fosseille-96-h groups or between the glyphosate-96-h and Fosseille-96-h groups (Figure 4B). Surprisingly, the control-12-h group showed an enzyme activity profile 1.4-fold lower than that of the control96-h group (Mann-Whitney, p1/40.01).

Variations in AChE activity between the 6 groups of turtles were observed (Kruskal-Wallis, $\mathrm{p}^{1 / 40.04}$ ). Pairwise comparisons revealed no significant variation between the groups sampled $12 \mathrm{~h}$ after exposure (Figure 5A). In addition, the glyphosate-96-h group showed an enzyme activity profile 1.8-fold lower than that of the control-96-h group (MannWhitney, $\mathrm{p}^{1 / 40.008)}$ ). The glyphosate-96-h group also showed an enzyme activity profile 2.1-fold lower than that of the Fosseille-96-h group (Mann-Whitney, $\mathrm{p}^{1 / 40.008)}$ ). No significant difference was observed between the control-96-h and Fosseille-96-h groups (Figure 5B).

\section{Quantification of lipid peroxidation within T. s. elegans}

Variations in levels of lipid peroxidation between the 6 groups of turtles were observed (Kruskal-Wallis,

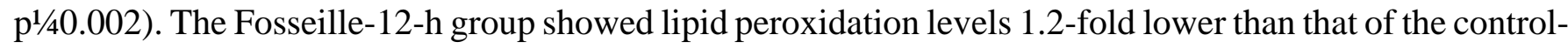
12-h group (MannWhitney, $\mathrm{p}^{1 / 40.032}$ ). No significant variation was observed between the control-12-h and glyphosate-12-h groups and between the glyphosate-12-h and Fosseille-12-h groups (Figure 6A). Similarly, the Fosseille-96-h group showed lipid peroxidation levels 1.7-fold lower than that of the control-96-h group (Mann-Whitney, $\mathrm{p}^{1 / 40.029)}$. No significant variation was observed between the control-96-h and glyphosate-96-h groups and between the glyphosate-96-h and Fosseille-96-h groups (Figure 6B). Surprisingly, the control-12-h group showed lipid peroxidation levels 1.7-fold higher than that of the control-96-h group (Mann-Whitney, p/40.016).

\section{Gene expression of CAT and SOD within M. leprosa}

The crossing threshold values $(\mathrm{Ct})$ obtained from CAT and SOD gene expression among all specimens of M. leprosa were higher than those obtained from the $18 \mathrm{~S}$ gene expression among the same specimens.

The $\mathrm{Ct}$ values were on average $36.5 \pm 0.28$ and $36.9 \pm 1.25$ for the 2 targeted CAT and SOD genes, respectively, and they were on average $23.5 \pm 1.2$ for the $18 \mathrm{~S}$ gene. Melting curves for all genes were similar to those obtained following preliminary tests conducted on mRNAs extracted from liver of captive adult red-eared sliders (data not shown). The low Ct values for the CAT and SOD genes thus reflect low levels of gene expression, as expected in unstressed turtles.

\section{Enzyme activity of CAT and SOD within M. leprosa}

Measures of CAT and SOD enzyme activity from blood samples were similar to those obtained following preliminary tests conducted on blood extracts of captive adult red-eared sliders (data not shown) 


\section{DISCUSSION}

\section{Evolution of oxidative stress over time: What lessons can we learn about experimental design?}

Reactive oxygen species (ROS), which are produced throughout intracellular metabolism, have physiological effects at low concentrations. However, if ROS are overproduced after environmental contaminations, they may have deleterious effects on cell structures, proteins, DNA, and lipids (see Gavric et al. [38] for a review). As a result, antioxidant enzymes, especially SOD and CAT, are activated to detoxify ROS and counteract their deleterious effects [39]. The first step in the detoxification process involves conversion of the superoxide anion $\left(\mathrm{O}_{2}^{-}\right)$to hydrogen peroxide $\left(\mathrm{H}_{2} \mathrm{O}_{2}\right)$ by the SOD enzyme and the second step consists in the conversion of $\mathrm{H}_{2} \mathrm{O}_{2}$ to water $\left(\mathrm{H}_{2} \mathrm{O}\right)$ and oxygen $\left(\mathrm{O}_{2}\right)$ by the CAT enzyme [40]. Nevertheless the sensitivity of both enzymes against ROS explains why SOD and CAT can be damaged by $\mathrm{H}_{2} \mathrm{O}_{2}$ and $\mathrm{O}_{2}{ }^{-}$, respectively. Consequently, SOD and CAT can be inactivated by these 2 components [41]. Finally, hydrogen peroxide, when not converted into water and oxygen, is metabolized into hydroxyl radicals $\left(\mathrm{OH}^{-}\right)$through the Fenton reaction. Hydroxyl radicals can react with lipids in the cell plasma membranes, which can cause extensive damage [42] (see Figure 7 for a schematic representation of the detoxification process).

The SOD enzyme activity profile for the control-12-h group was 1.4-fold lower than that of the control-96$\mathrm{h}$ group, which was unexpected. A similar result was obtained between the control-12-h and control-96-h groups for CAT activity, the enzyme activity profile being 1.7-fold higher in the control-12-h group. These results indicated that at least one of the turtle control groups was stressed, although all turtles were maintained in tap water without any source of pollutant under experimental conditions. Because SOD activity was not statistically different between the control-12-h, Fosseille12-h, and glyphosate-12-h groups, contrary to what happened at $96 \mathrm{~h}$, it is very likely that the control-12-h group could have been stressed. The dissimilar enzyme activity profiles between the SOD control-12-h and control-96-h groups thus suggest that SOD could have been inactivated by $\mathrm{H}_{2} \mathrm{O}_{2}$, whereas the dissimilar enzyme activity profiles between the CAT control12-h and control-96-h groups suggest that CAT could have been activated by $\mathrm{H}_{2} \mathrm{O}_{2}$. Because gene expression between the SOD control-12-h and control-96-h groups was similar, as was the case for the CAT control-12-h and control-96-h groups, stress induced at $12 \mathrm{~h}$ would imply only enzyme activity and no gene transcription.

Regarding our experimental design, 2 groups of 15 turtles each were acclimated for 2 mo at the laboratory in 20-L water tanks. Containers were first equipped with UV lamps and basking sites. Turtles were subsequently divided into 6 groups of 5 individuals per group in tanks devoid of basking sites and filled with $5 \mathrm{~cm}$ of water, which constituted the experimental groups that were sampled at $12 \mathrm{or} 96 \mathrm{~h}$. Although turtles were acclimated for a period of $60 \mathrm{~d}$, they might have been stressed soon after the beginning of the experiments. We identified several reasons that could explain the variations in antioxidant enzyme activity: 1) turtle handling when organizing the 6 experimental groups of animals; 2) turtle feeding, which was interrupted during the experimental process; 3 ) impossibility for turtles to swim because of very low levels of water in tanks; and 4) absence of artificial basking sites, preventing basking and/or hiding activities. The last setting (i.e., the absence of basking sites) was selected to force turtles to be always in contact with the water and consequently with the contaminant, if any. Variations in enzyme activity were also observed by others among the control groups sampled at different phases but, to our knowledge, have never been discussed [20,21]. The present study thus highlights the importance of replicating control groups and comparing only groups challenged at the same interval of time. In the present study, because we showed that animals may be slightly stressed at $12 \mathrm{~h}$, even in the absence of contaminant, comparisons between exposed and control groups will be studied only at $96 \mathrm{~h}$ after the beginning of experiments. 


\section{Evolution of oxidative stress in animals challenged with pesticides and polluted water}

Comparisons of SOD enzyme activity between the glyphosate-96-h and control-96-h groups illustrated differences in the activity profiles, which were 1.6-fold higher in the control-96-h group. However, SOD gene expression was 3.4-fold higher in the glyphosate-96-h group. If comparisons of CAT enzyme activity between the glyphosate-96-h and control-96-h groups also illustrated differences in the activity profiles, these were, however, 1.5-fold higher in the glyphosate96-h group. Similarly, CAT gene expression was 2.8-fold higher in the glyphosate-96-h group. Regarding the detoxification process of ROS, which involves transformation of $\mathrm{O}_{2}^{-}$in $\mathrm{H}_{2} \mathrm{O}_{2}$ and transformation of $\mathrm{H}_{2} \mathrm{O}_{2}$ in $\mathrm{H}_{2} \mathrm{O}$ and $\mathrm{O}_{2}$ through SOD and CAT activities, respectively, and down-regulation of both enzymes following production of $\mathrm{O}_{2}{ }^{-}$and $\mathrm{H}_{2} \mathrm{O}_{2}$ (see Figure 7), it is likely that the SOD enzyme was inactivated whereas the CAT enzyme was activated in turtles challenged with high concentrations of glyphosate-based herbicide. Catalase activation also supposes that the SOD enzyme already catalyzed $\mathrm{O}_{2}{ }^{-}$in $\mathrm{H}_{2} \mathrm{O}_{2}$, which means that SOD activation occurred quite early, before $96 \mathrm{~h}$. Assuming that the commercial formulation used during experiments induced a stress, concentrations of $\mathrm{H}_{2} \mathrm{O}_{2}$ in organisms must have increased substantially. Because the lipid peroxidation levels were not significantly different between the glyphosate-96-h and control-96-h groups, which indicated that $\mathrm{H}_{2} \mathrm{O}_{2}$ was not metabolized in $\mathrm{OH}^{-}$, this suggests that $\mathrm{H}_{2} \mathrm{O}_{2}$ was catalyzed in $\mathrm{H}_{2} \mathrm{O}$ and $\mathrm{O}_{2}$. The lipid peroxidation measure then supports our hypothesis about an activation of the CAT enzyme. The present results therefore illustrate an oxidative stress effect of the glyphosate-based herbicide under experimental conditions, which has been already documented among many aquatic or semi-aquatic vertebrate species, such as fishes, amphibians, and reptiles [17-24,43]. The AChE activity, which was lower in the glyphosate-96-h group in comparison to the control-96-h group, emphasizes a stress induced by this contaminant, as illustrated in fishes [18,21].

Comparisons of SOD enzyme activity between the Fosseille96-h and control-96-h groups did not illustrate statistical differences in the activity profiles, though SOD enzyme activity was slightly lower in the Fosseille-96-h group. However, the gene expression for the SOD enzyme was 2.2-fold higher in the Fosseille-96-h group. On the contrary, comparisons of CAT enzyme activity between the Fosseille-96-h and control-96-h groups illustrated differences inthe activity profiles, which were 1.9-fold higher in the Fosseille-96-h group. The gene expression for the CAT enzyme was 2.1-fold higher in the Fosseille-96-h group. Overall, the patterns of gene expression and enzyme activity of the SOD and CAT enzymes were similar for the Fosseille-96-h and glyphosate-96-h groups. Regarding lipid peroxidation levels, they were significantly lower in the Fosseille-96-h group, which indicated that $\mathrm{H}_{2} \mathrm{O}_{2}$ was not metabolized in $\mathrm{OH}^{-}$but was catalyzed in $\mathrm{H}_{2} \mathrm{O}$ and $\mathrm{O}_{2}$ as stated for the glyphosate-96-h group. Therefore, if the lipid peroxidation measure also supportsthe hypothesis about activation of the CAT enzyme, these results illustrate an oxidative stress effect induced by the water collected in the Fosseille River. Because the AChE activity was not statistically different between the Fosseille-96-h and control-96-h groups, it is likely that the glyphosatebased herbicide was probably not the main stressor involved in the physiological response of turtles [17,21]. Other contaminants may be thereby advocated to explain the molecular and biochemical variations in turtles challenged with the Fosseille water. Because wastewater treatments are used to convert the quality of waters that feed the Fosseille River, it is likely that a cocktail of chemicals may be the source of turtle stress. To conclude, surveying M. leprosa turtles of theFosseilleRiverremainsacentralissuetoassesstheimpactof the poor quality of waters on this species specifically and on biodiversity in general. Turtles may be indeed an excellent model to follow variations in water quality because these animals are globally less sensitive than amphibians, which are lacking in this river.

Investigation of gene expression and enzyme activity from turtle blood samples: New perspectives in the disciplinary field of environmental ecotoxicology 
Measures of the gene expression and enzyme activity of SOD and CAT biomarkers in the Mediterranean pond turtle M. leprosa were conclusive. The results showed that the profiles of gene expression and activity of antioxidative stress enzymes could be quantified, indicating that this approach can be performed not only from organs such as liver, heart, brain, and kidneys [17,20,44], but also from blood samples. With the exception of the study of Labrada-Martagon et al. [45] that was completed from the quantification of enzyme activity among blood samples of sea turtles, the present study is the first to report gene expression profiles from blood. The results obtained overall indicate that this procedure for assessing oxidative stress can be used without killing animals. This technique can therefore be applied to a great diversity of animals, especially animals that are threatened with extinction. This is particularly true in the study of LabradaMartagon et al. [45], which focused on the Eastern Pacific green sea turtle in 2 contrasted coastal lagoons. Regarding the increase of threats to species, this approach thus offers new perspectives in the disciplinary field of environmental ecotoxicology because it will allow the study of wild populations without the euthanizing of hosts, on the one hand, and the survey of the same individuals after recapture in natural environments, on the other.

\section{Acknowledgment}

We are grateful to G. Simon for his technical help during the experimental design and to J. Boissier for his advice on statistics. We also thank J. Quief and Ms. Malirach for providing T. s. elegans juveniles born at the Turtles Farm of Sorede (France) and B. Ragot for experimental facilities on M. leprosa at the Zoodyssee Zoological Park of Chize (France). Financial support for the present study was provided by grants from the CNRS, region Languedoc-Roussillon and Veolia Eau Perpignan. 


\section{REFERENCES}

1. Dudgeon D, Arthington AH, Gessner MO, Kawabata ZI, Knowler DJ, Levêque C, Naiman RJ, PrieurRichard AH, Soto D, Stiassny MLJ, Sullivan CA. 2006. Freshwater biodiversity: Importance, threats, status and conservation challenges. Biol Rev 81:163-182.

2. Balian EV, Segers H, Leveque C, Martens, K. 2008. The freshwater animal diversity assessment: An overview of the results. Hydrobiologia 595:627-637.

3. Strayer DL, Dudgeon D. 2010. Freshwater biodiversity conservation: Recent progress and future challenges. J N Am Benthol Soc 29:344-358.

4. Abell R. 2002. Conservation biology for the biodiversity crisis: Afreshwater follow-up. Conserv Biol 16:1435-1437.

5. Revenga C, Mock G. 2000. Freshwater biodiversity in crisis. EarthTrends. World Resources Institute, Washington, DC, USA.

6. Baron JS, LeRoy Poff N, Angermeier PL, Dahm CN, Gleick HairstonGN Jr, Jackson RB, Johnston CA, Richter BD, Steinman AD. 2003. Sustaining healthy freshwater ecosystems. Issues in Ecology 10:1-16.

7. Vaughn CC. 2010. Biodiversity losses and ecosystem function in freshwaters: Emerging conclusions and research directions. BioScience 60:25-35.

8. Hupfer M, Kleeberg A.2007.Stateandpollutionoffreshwaterecosystems - Warning signals of a changing environment. In Lozan JL, Grassl H, Hupfer P, Menzel L, Schönwiese CP, eds, Global Change: Enough Water for All? Wissenschaftliche Auswertungen, Hamburg, Germany, pp 126-132.

9. Villeneuve A, Humbert JF, Larroude S. 2011. Herbicide Contamination of Freshwater Ecosystems: Impact on Microbial Communities. INTECH, Rijeka, Croatia.

10. Reoyo-Prats B, Aubert D, Menniti C, Ludwig W, Sola J, Pujo-Pay M,Conan P, Verneau O, Palacios C. 2017. Multicontamination phenomena occur more often than expected in Mediterranean coastal water courses: Study case of the T^et River (France). Sci Total Environ 579:10-21.

11. Commissariat General au Developpement Durable. 2015. Les pesticides dans les cours d'eau Francais en 2013. Chiffres etS Statistiques. [cited 2016 September 16]. Available from: http://www. statistiques.developpement-durable.gouv.fr/publications/p/2348/1108/ pesticides-cours-deaufrancais-2013.html

12. Giesy JP, Dobson S, Solomon KR. 2000. Ecotoxicological riskassessment for Roundup herbicide. Rev Environ Contam T 167:35-120.

13. Howe CM, Berrill M, Pauli BD, Helbing CC, Werry K, Veldhoen N. 2004. Toxicity of glyphosatebased pesticides to four North American frog species. Environ Toxicol Chem 23:1928-1938.

14. Peixoto F. 2005. Comparative effects of the Roundup and glyphosate on mitochondrial oxidative phosphorylation. Chemosphere 61:1115-1122.

15. Richard S, Moslemi S, Sipahutar H, Benachour N, Seralini GE. 2005. Differential effects of glyphosate and Roundup on human placental cells and aromatase. Environ Health Persp 113:716720.

16. Gasnier C, Dumont C, Benachour N, Clair E, Chagnon MC, Seralini GE. 2009. Glyphosate-based herbicides are toxic and endocrine disruptors in human cell lines. Toxicology 162:184-191.

17. Glusczak L, dos Santos Miron D, Crestani M, Braga da Fonseca M, deAraujo Pedron F, Duarte MF, Vieira VLP. 2006. Effect of glyphosate herbicide on acetylcholinesterase activity and metabolic and hematological parameters in piava (Leporinus obtusidens). Ecotox Environ Safe 65:237-241.

18. Glusczak L, dos Santos Miron D, Moraes BS, Sim oes RR, Schetinger MRC, Morsch VM, Loro VL. 2007. Acute effects of glyphosate herbicide on metabolic and enzymatic parameters of silver catfish (Rhamdia quelen). Comp Biochem Phys C 146:519-524. 
19. Cavalcante DGSM, Martinez CBR, Sofia SH. 2008. Genotoxic effects of Roundup on the fish Prochilodus lineatus. Mutat Res-Gen Tox En 655:41-46.

20. Langiano V do C, Martinez CBR. 2008. Toxicity and effects of aglyphosate-based herbicide on the neotropical fish Prochilodus lineatus. Comp Biochem Phys C 147:222-231.

21. Modesto KA, Martinez CBR. 2010. Roundup ${ }^{1}$ causes oxidative stress in liver and inhibits acetylcholinesterase in muscle and brain of the fish Prochilodus lineatus. Chemosphere 78:294-299.

22. Relyea RA. 2005. The lethal impact of Roundup on aquatic andterrestrial amphibians. Ecol Appl 15:1118-1124.

23. Relyea RA. 2005. The impact of insecticides and herbicides on thebiodiversity and productivity of aquatic communities. Ecol Appl 15:618-627.

24. Costa MJ, Monteiro DA, Oliveira-Neto AL, Rantin FT, Kalinin AL.2008. Oxidative stress biomarkers and heart function in bullfrog tadpoles exposed to Roundup Original ${ }^{1}$. Ecotoxicology $17: 153-163$.

Conseil General des Pyrenees-Orientales. 2013. Suivi de la qualite des cours d'eau du bassin versant $\mathrm{du}$ Tech et des petits fleuves $\mathrm{c}^{\wedge}$ otiers, rapport final, annees 2011/2012. Perpignan, France.

26. Palacios C, Urrutia C, Knapp N, Quintana MF, Bertolero A, Simon G, Du Preez LH, Verneau O. 2015. Demographic structure and genetic diversity of Mauremys leprosa in its northern range reveal new populations and a mixed origin. Salamandra 51:221-230.

27. UICN Comite France, Museum National d'Histoire Naturelle, Societe Herpetologique de France. 2015. La liste rouge des especes menacees en France-Chapitre reptiles et amphibiens de France metropolitaine. Paris, France.

28. Vazquez M. 2012. Dynamique de la population d'emydes lepreuses - Mauremys leprosa. Site Natura 2000 "Massif des Alberes/Banyuls-surMer." Master's dissertation. Universite de Perpignan Via Domitia, Perpignan, France.

29. Polo-Cavia N, Lopez P, Martin J. 2009. Interspecific differences in chemosensory responses of freshwater turtles: Consequences for competition between native and invasive species. Biol Invasions 11:431-440.

30. Polo-Cavia N, LopezP, Martin J.2010. Competitiveinteractions duringbasking between native and invasive freshwater turtle species. Biol Invasions 12:2141-2152.

31. Polo-Cavia N, Lopez P, Martin J. 2011. Aggressive interactions duringfeeding between native and invasive freshwater turtle species. Biol Invasions 13:1387-1396.

32. Meyer L, Du Preez LH, Bonneau E, Heritier L, Quintana M, Valdeon A, Sadaoui A, Kechemir-Issad N, Palacios C, Verneau O. 2015. Parasite host-switching from the invasive American red-eared slider, Trachemys scripta elegans, to the native Mediterranean pond turtle, Mauremys leprosa, in natural environments. Aquat Invasions 10:79-91.

33. Lushchak OV, Kubrak OI, Storey JM, Storey KB, Lushchak VI. 2009. Low toxic herbicide Roundup induces mild oxidative stress in goldfish tissues. Chemosphere 76:932-937.

34. Jiraungkoorskul W, Upatham ES, Kruatrachue M, Sahaphong S, Vichasri-Grams S, Pokethitiyook P. 2002. Histopathological effects of Roundup, a glyphosate herbicide, on Nile tilapia (Oreochromis niloticus). Science Asia 28:121-127.

Mann RM, Bidwell JR. 1999. The toxicity of glyphosate and severalglyphosate formulations to four species of southwestern Australian frogs. Arch Environ Con Tox 36:193-199.

Livak KJ, Schmittgen TD. 2001. Analysis of relative gene expressiondata using real-time quantitative PCR and the $2^{\text {DDCT }}$ method. Methods 25:402-408.

37. Lowry OH, Rosenbrough NJ, Faar AL, Randall RJ. 1951. Proteinmeasurements with the Folin phenol reagent. J Biol Chem 193:265-275.

38. Gavric J, Prokic M, Despotovic S, Gavrilovic B, Radovanovic T, Borkovic-Mitic S, Pavlovic S, Saicic Z. 2015. Biomarkers of oxidative stress and acetylcholinesterase activity in the blood of grass 
snake (Natrix natrix L.) during prehibernation and posthibernation periods. Braz Arch Biol Techn 58:443-453.

39. Van der Oost R, Beyer J, Vermeulen NP. 2003. Fish bioaccumulationand biomarkers in environmental risk assessment: A review. Environ Toxicol Phar 13:57-149.

40. Halliwell B. 2001. Free radicals and other reactive species in disease. InEncyclopedia of Life Sciences. Nature Publishing Group, London, UK.

41. Hermes-Lima M, Storey KB. 1993. Antioxidant defenses in thetolerance of freezing and anoxia by garter snakes. Am J Physiol 265:646-652.

42. Hermes-Lima M. 2004. Oxygen in biology and biochemistry: Role offree radicals. In Storey KB, ed, Functional Metabolism: Regulation and Adaptation. John Wiley and Sons, Hoboken, NJ, USA, pp 319-368.

43. Poletta GL, Larriera A, Kleinsorge E, Mudry MD. 2009. Genotoxicity of the herbicide formulation Roundup (glyphosate) in broad-snouted caiman (Caiman latirostris) evidenced by the comet assay and the micronucleus test. Mutat Res-Gen Tox En 672:95-102.

44. Bagnyukova TV, Lushchak OV, Storey KB, Lushchak VI. 2007. Oxidative stress and antioxidant defense responses by goldfish tissues to acute change of temperature from 3 to 238C. J Therm Biol 32:227-234.

45. Labrada-Martagon V, Tenorio Rodriguez PA, Mendez-Rodriguez LC, Zenteno-Savin T. 2011. Oxidative stress indicators and chemical contaminants in east Pacific green turtles (Chelonia mydas) inhabiting two foraging coastal lagoons in the Baja California peninsula. Comp Biochem Phys C 154:65-75. 


\section{FIGURE 1}
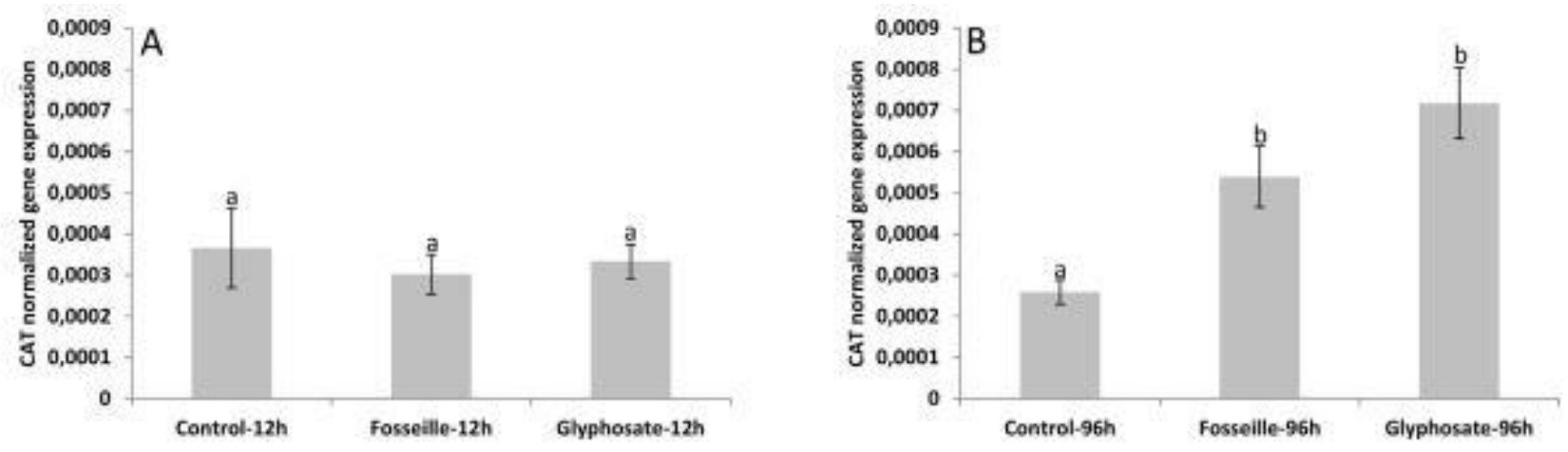

Comparison of catalase (CAT) gene expression between the control, Fosseille, and glyphosate groups after $12 \mathrm{~h}$ (A) and $96 \mathrm{~h}$ (B) of exposure. Data sets were normalized to the $18 \mathrm{~S}$ rRNA gene reference. Statistically significant differences $(\mathrm{p}<0.05)$ within experimental groups are illustrated with lowercase letters. Values are means \pm standard error of the mean. Number of animals $1 / 45$ per experimental group. 


\section{Figure 2}
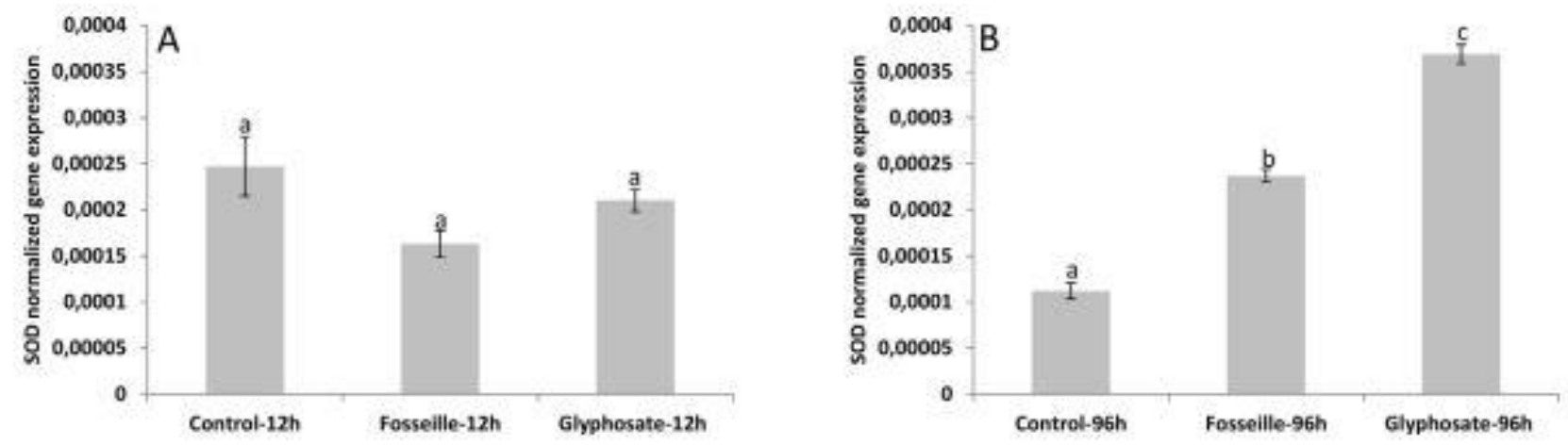

Comparison of superoxide dismutase (SOD) gene expression between the control, Fosseille, and glyphosate groups after $12 \mathrm{~h} \mathrm{(A)}$ and $96 \mathrm{~h}$ (B) of exposure. Data sets were normalized to the 18S rRNA gene reference. Statistically significant differences $(\mathrm{p}<0.05)$ within experimental groups are illustrated with lowercase letters. Values are means \pm standard error of the mean. Number of animals $1 / 45$ per experimental group. 


\section{Figure 3}
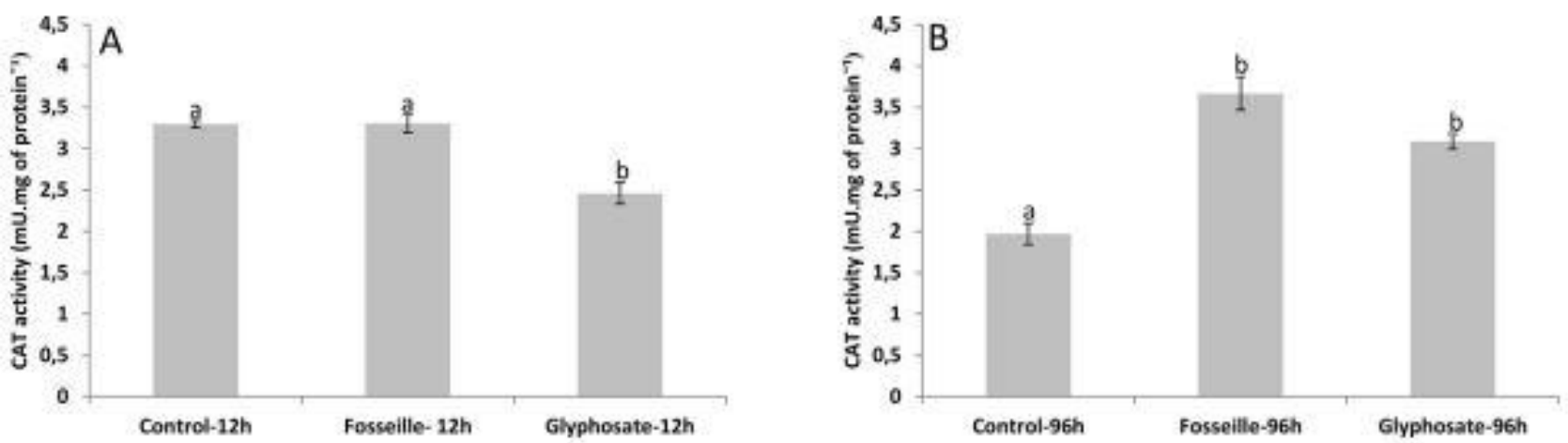

Comparison of catalase (CAT) activity between the control, Fosseille, and glyphosate groups after $12 \mathrm{~h}$ (A) and $96 \mathrm{~h}(\mathrm{~B})$ of exposure. Statistically significant differences $(\mathrm{p}<0.05)$ within experimental groups are illustrated with lowercase letters. Values are means \pm standard error of the mean. Number of animals $1 / 45$ per experimental group. 


\section{Figure 4}
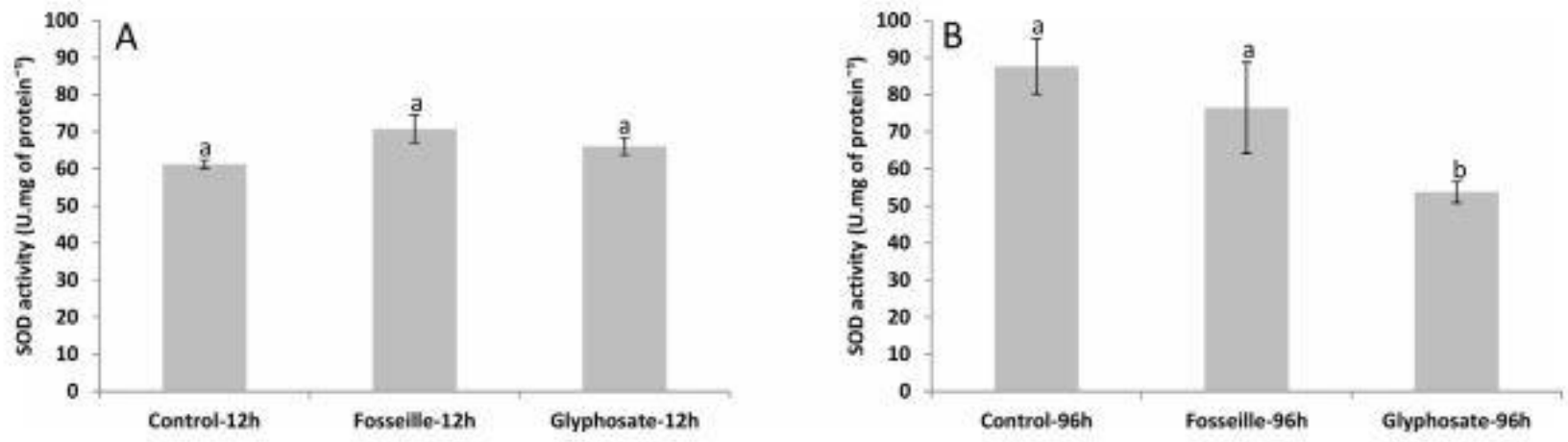

Comparison of superoxide dismutase (SOD) activity between the control, Fosseille, and glyphosate groups after $12 \mathrm{~h}(\mathrm{~A})$ and $96 \mathrm{~h}(\mathrm{~B})$ of exposure. Statistically significant differences $(\mathrm{p}<0.05)$ within experimental groups are illustrated with lowercase letters. Values are means \pm standard error of the mean. Number of animals $1 / 45$ per experimental group. 
Figure 5
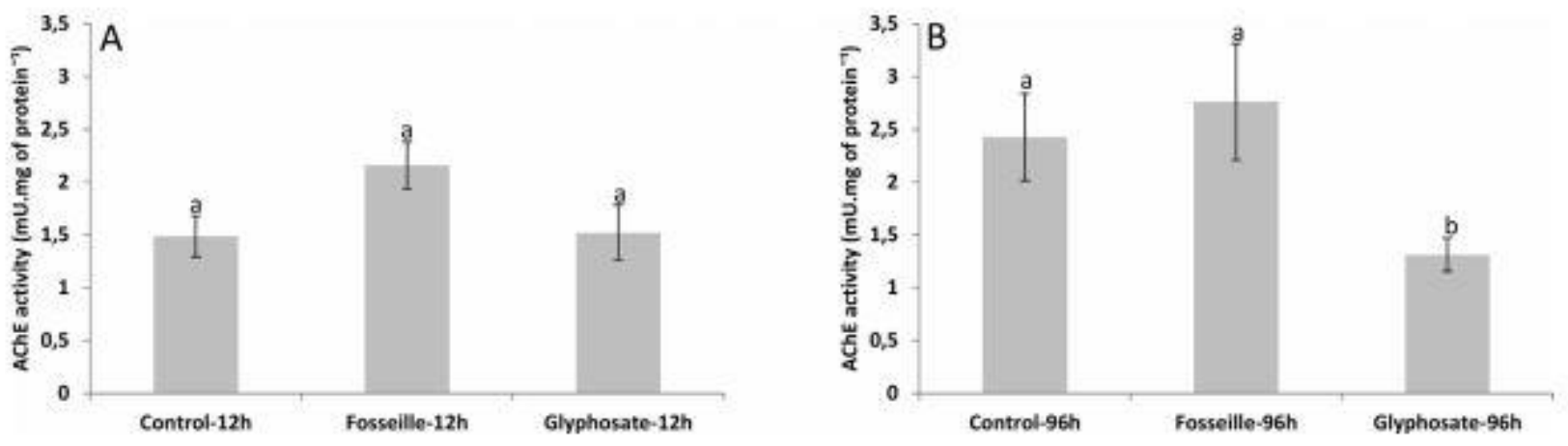

Comparison of acetylcholinesterase (AChE) activity between the control, Fosseille, and glyphosate groups after $12 \mathrm{~h}(\mathrm{~A})$ and $96 \mathrm{~h}(\mathrm{~B})$ of exposure. Statistically significant differences ( $\mathrm{p}<0.05)$ within experimental groups are illustrated with lowercase letters. Values are means \pm standard error of the mean. Number of animals $1 / 45$ per experimental group. 


\section{Figure 6}
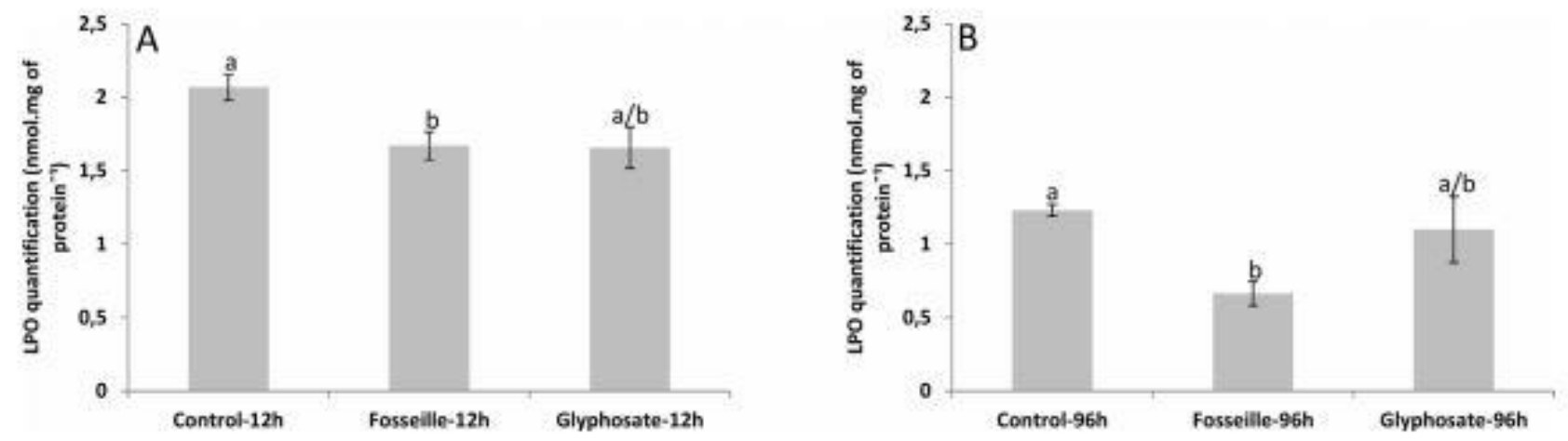

Comparison of lipid peroxidation (LPO) quantification between the control, Fosseille, and glyphosate groups after $12 \mathrm{~h}$ (A) and $96 \mathrm{~h}$ (B) of exposure. Statistically significant differences $(\mathrm{p}<0.05)$ within experimental groups are illustrated with lowercase letters. Values are means \pm standard error of the mean. Number of animals $1 / 45$ per experimental group 


\section{Figure 7}

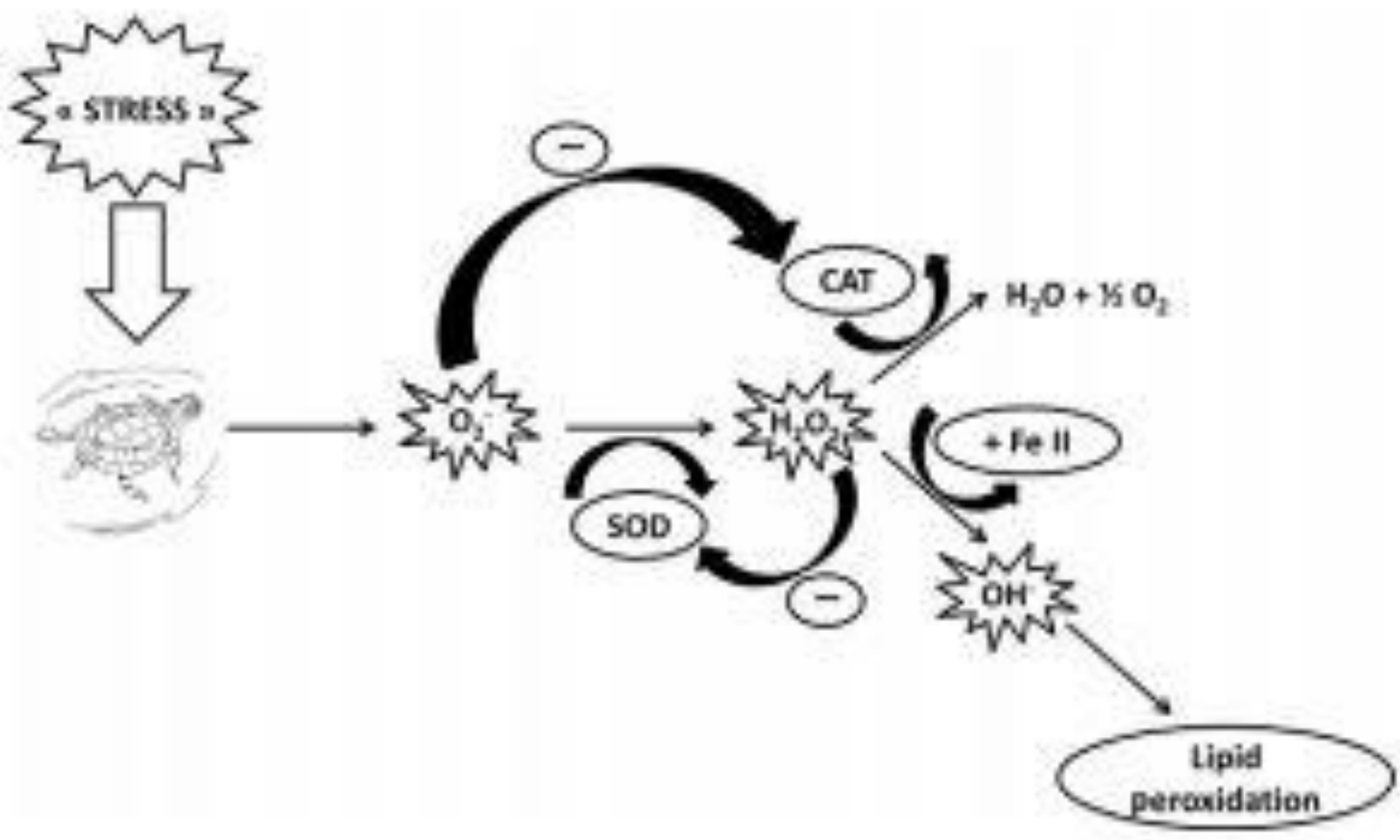

Schematic representation of lipid peroxidation and detoxification processes involving antioxidant superoxide dismutase (SOD) and catalase (CAT) enzymes (modified after Haliwell [40] and Hermes-Lima [42]). 